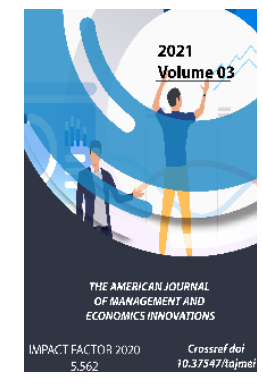

Journal Website: https://theamericanjou rnals.com/index.php/ta jmei

Copyright: Original content from this work may be used under the terms of the creative commons attributes 4.0 licence.

\section{Important Estimates Of Payment Accounting In The Transition Of Uzbekistan To International Financial Reporting Standards}

\author{
Abdurakhim Nortojiyevich Turayev \\ DSc, Professor The Department "Financial Analysis And Audit”, Sciences Tashkent State \\ University Of Economics, Tashkent, Uzbekistan
}

Abdukhamid Sattorovich Umarov

Associate Professor Of Department "Informatics And Management" National Institute Of Fine Arts And Design Named After Kamoliddin Behzod, Tashkent, Uzbekistan

\title{
ABSTRACT
}

In the context of innovative development of the economy, the number of enterprises engaged in foreign trade operations and foreign investments is growing. This article describes the shortcomings of the payment system, international standards of impartiality of information, the priorities of decision-making in Uzbekistan and, above all, the priorities of decision-making, as well as the corresponding conclusions and recommendations for their elimination.

\section{KEYWORDS}

Financial Reporting, International Financial Reporting Standards (IFRS), Remuneration, New Remuneration System.

\section{INTRODUCTION}

In recent years, the process of integrating our economy into the world market has been consistent. In particular, the ongoing socioeconomic reforms are aimed at ensuring longterm sustainable economic growth by increasing production efficiency in all sectors and sectors of the economy. The integration of Uzbekistan into world business requires the presentation of financial statements of local enterprises interested in cooperation with international investors in a clear, transparent, reliable and clear form in accordance with generally accepted rules in accordance with the requirements of international standards. It is necessary to take a number of positive steps in the field of accounting and auditing in 
accordance with international standards in order to improve investment policy and attract foreign investment to ensure political and macroeconomic stability. The transition to IFRS will also lead to a radical reform of accounting. In particular, this creates the need for a complete restructuring of the wage system. Using IFRS, the company has the opportunity to enter international markets, thereby increasing the number of vestors. The main advantage of accounting in accordance with IFRS is also improving the quality of management information.

\section{ANALYSIS OF LITERATURE ON THE TOPIC}

Personnel is a collection of employees of different professional qualification groups who are employed at the enterprise and are included in the staff of the enterprise. A.Golovacheva. Wages are defined as follows: "Wages for an employee are the main and main source of his personal income, which is the main means of ensuring and increasing the welfare of him and his family" [1].

In accordance with changes in the economic and social development of the country, the policy in the field of wages, social support and protection is also changing significantly workers. These changes require serious study and use of many fundamental provisions adopted in advanced economies. In the economic literature, remuneration is considered as cash payment. labor of employees in the form of wages and bonuses, depending on the number and the quality of work.

Payroll accounting has always been one of the most time consuming areas of accounting. This is due to the variety of forms and systems of remuneration of the enterprise, the variety of primary documents and the specifics of methods for calculating wages. Kasyanova G.Yu. "Wage. A practical guide for an accountant "reads". One of the important areas of accounting for any company is the payroll system. This is one of the central positions in the accounting system" [2].

Remuneration in Uzbekistan is regulated by the following regulations: the Labor Code of the Republic of Uzbekistan, the Civil Code of the Republic of Uzbekistan, the Tax Code of the Republic of Uzbekistan, the Law on Accounting, IFRS, corporate accounting policy and others. The lack of a clear regulatory document governing payroll accounting is a serious shortcoming of the payroll system. [3].

In foreign practice, all aspects of payroll are reflected in a single document - IFRS 19 "Employee incentives". There is no concept of "salary" in IFRS, but the term "employee incentives" is used. In accordance with IFRS 19, employee incentives include all types of salaries paid to employees, including bonuses, bonuses, etc. [4].

It should be noted that IFRS is just a set of principles and requirements according to which countries prefer to work independently. B.G.Maslov and B.N.Nikitenko "One of the main problems in the implementation of international standards in all countries is the lack of qualified specialists" [5].

Unfortunately, there are not enough IFRS specialists in Uzbekistan. Below we will consider the features and problems of accounting for wages in Uzbekistan during the transition to IFRS.

\section{RESEARCH METHODOLOGY}

The article uses methods such as the analysis of published scientific literature on payroll and 
the transition to IFRS, accounting procedures, data processing and comparison.

\section{ANALYSIS AND RESULTS}

At present, in Uzbekistan, the salary groups of employees in accounting are not standardized by any documents. However, the payroll includes:

- Direct payments depending on the number of hours worked or the amount of work performed;

- Payment for non-working hours;

- One-time incentive payments;

- Social payments.

In IFRS, payments in various forms are classified in terms of costs and disclosures in financial statements, while in Uzbekistan, on the contrary, they are grouped according to the nature of the production process and the sources that cover wages. IFRS 19 divides salaries into the following categories:

1) Short-term employee benefits;

2) Wages after work;

3) Retirement pension;

4) Compensation payments;

5) Long-term payments.

However, short-term payments include:

6) Wages and social security contributions;

7) Short-term paid vacation;

8) Non-cash wages.
In the case when an employee provides services to the company during the reporting period, the entity should recognize the unrecounted amount of the short-term urgent benefits to these employees, which are payable in total me for these services:

1) As a liability (after deducting all amounts already paid);

2) As an expense (except for those amounts of remuneration that another IFRS requires or permits inclusion in the cost of the asset).

In accordance with IFRS, short-term employee benefits are accounted for on a straight-line basis and are measured, however, on a nondiscounted basis. Commitments to profit sharing plans and premiums arises in connection with the services provided by the employee, therefore the company recognizes the costs of the profit-sharing plans and the payment of bonuses as an expense, and not as distribution of net profit. With regard to longterm employee benefits, they include payments for more than twelve months after the end of the period. For example, seniority leave, anniversary payments, or other benefits for the length of service.

Also, in IFRS19 post-employment benefits classified into defined contribution and defined benefit plans. With respect to defined contribution plans, the entity carries out fixed contributions to a separate, independent legal entity, i.e. to the pension fund, therefore, the organization's liabilities are limited to a certain amount that it agrees to contribute to this fund. The amount of pension payments will be determined by the value contributions of the organization or the employee and the amount of income on the invested funds in this a fund that had the opportunity to use them for their own purposes. 
In table first, we will conduct a comparative characteristic of the accounting methodology employee benefits in international and Uzbek practice'1.

Table №1

\begin{tabular}{|c|c|c|}
\hline $\begin{array}{c}\text { Identification accounting } \\
\text { object }\end{array}$ & International practice & Uzbek practice \\
\hline $\begin{array}{l}\text { Economic content accounting } \\
\text { object }\end{array}$ & $\begin{array}{c}\text { short term reward, reward } \\
\text { upon graduation labor activity, } \\
\text { other long-term remuneration } \\
\text { to employees, severance pay, } \\
\text { compensation payments } \\
\text { equity instruments }\end{array}$ & $\begin{array}{c}\text { salary fund (main and } \\
\text { additional), social payments } \\
\text { nature, expenses, not } \\
\text { accounted for in the fund } \\
\text { wages and benefits social } \\
\text { nature }\end{array}$ \\
\hline $\begin{array}{l}\text { Regulatory legal regulation } \\
\text { accounting object }\end{array}$ & IFRS 19 "Employee benefits" & $\begin{array}{l}\text { system of normative legal } \\
\text { regulation accounting of } \\
\text { expenses for payment labor } \\
\text { and deductions for social } \\
\text { needs }\end{array}$ \\
\hline $\begin{array}{c}\text { Used accounting account } \\
\text { rewards }\end{array}$ & $\begin{array}{c}\text { on one's own system under } \\
\text { development accounts in the } \\
\text { organization }\end{array}$ & $\begin{array}{l}\text { account } 6700 \text { "Settlements } \\
\text { with payroll personnel" }\end{array}$ \\
\hline Grade rewards & $\begin{array}{l}\text { Undiscounted and discounted } \\
\text { value price, fair value }\end{array}$ & undiscounted value price \\
\hline $\begin{array}{c}\text { Reflection in reporting } \\
\text { information about reward } \\
\text { employees }\end{array}$ & $\begin{array}{l}\text { disclosure requirements } \\
\text { information in financial } \\
\text { reporting developed according } \\
\text { to each of the five groups of } \\
\text { payments }\end{array}$ & $\begin{array}{l}\text { debt information in front of } \\
\text { staff organization is revealed } \\
\text { in financial, tax reporting }\end{array}$ \\
\hline
\end{tabular}

Considering National Accounting Standards and IFRS in the payroll comparison method, we can say that National Accounting Standards differs from IFRS in some respects, IFRS is the basis for organizing more accurate and uniform accounting than National Accounting Standards. Accordingly, a number of measures have been taken in Uzbekistan to organize accounting and payroll accounting, which is its sensitive part, based on IFRS. In particular, a clear example of this is the Resolution of the President of the Republic of Uzbekistan dated February 24, 2020 No. PP-4611 "On additional measures for the transition to International Financial Reporting Standards (IFRS)" [6].

In accordance with this regulatory document, since January 2020, topical issues have been identified, such as a radical revision of the process of preparation and approval of business entities for the transition to IFRS.

1. From the end of 2021, a list of persons has been drawn up who will be required to prepare financial statements based on IFRS. The list includes joint stock companies, commercial banks, insurance

\footnotetext{
${ }^{1}$ compiled by the authors
} 
companies and legal entities that are classified as large taxpayers. It is envisaged that from January 1, 2021, they will organize accounting based on IFRS, provide adequate accounting personnel for the high-quality application of international standards.

2. Taking into account the need to train a large number of qualified specialists with sufficient knowledge and skills, the issues of organizing activities were also identified on the basis of a completely new integrated approach to training national personnel.

Considering this issue from the side of one of the main advantages of using IFRS - reliability and maximum transparency of the presented financial statements, it is also impossible to treat this only from the positive side. Both the accountant who draws up such reports and the user, both external and internal, must have a certain level of professional knowledge: the first in order to correctly draw up these reports, the second - to evaluate and analyze. An accountant who does not have the necessary knowledge and skills to apply the adopted provisions is likely to make mistakes, which, of course, will lead to distortion of the financial statements. In addition, international standards suggest that an accountant must have professional judgment, which is subjective in nature, and therefore can lead to even greater incompatibility of reporting. Professional judgment also creates the basis for the manipulation of financial statements in the face of an accountant's dishonesty.

Currently, the focus is on the implementation of the digital economy in all sectors and industries of the country. Relevant regulatory documents have also been adopted. However, in practice, in the activities of business entities related to the organization of payroll accounting and control, old concepts, reporting forms, chart of accounts, standards, methodology, paperwork and redundancy that do not meet today's requirements are used. survived. In particular, in banks, non-bank credit institutions, insurance companies that are part of the financial sector of the economy, as well as in some large joint-stock companies, financial reporting forms, charts of accounts.

\section{CONCLUSIONS}

Comparing National Accounting Standards and IFRS, we faced a number of problems in the remuneration system in Uzbekistan. In the international standard and the system for remuneration of employees, there is no uniformity in many ways. Studying foreign accounting experience can help Uzbek companies to improve their efficiency.

Improving payroll accounting based on IFRS is becoming one of the most pressing issues.

Therefore, we consider it expedient to solve the above problems with intensity, consistency and determination in the shortest possible time and make the following suggestions:

1. Fundamentally reform the wage system based on IFRS and develop a new system. Adoption of a single regulatory document governing and controlling payroll, which should be based on IFRS 19 and include all processes and timing of payroll, regulatory standards;

2. It is necessary to decisively accelerate the full implementation of IFRS in the activities of all sectors and industries of the economy at enterprises and organizations, as well as budgetary organizations and institutions of the state system, in general, commercial and non-profit organizations. - legal entities. At the same time, we consider it 
expedient to digitize all financial and accounting processes in accounting, create software algorithms and widely and effectively use them according to the principle of "Unified chart of accounts, unified report and unified software."

Analyzing IFRS 19 Employee Benefits, it is clear that in the system of remuneration there is a number of shortcomings, but despite this, the emergence of a new system should eliminate a significant gap in the regulatory framework of accounting. The implementation of these proposals and recommendations will serve to improve payroll accounting in Uzbekistan, as well as to further expand and improve the ongoing reforms in the field of accounting and auditing, thereby attracting more investment in the economy and strengthening integration processes. We believe that this will allow us even more to increase our export potential and competitiveness.

\section{REFERENCES}

1. Golovacheva A. "Organization, regulation and remuneration" Moscow: New knowledge, 2007.

2. Kasyanova G.Yu. "Wage. A Practical Guide for an Accountant "; 4th edition, revised and enlarged. - M.: Abak, 2015. 768 p.

3. Dzhumanov S.A. Compilation of financial reporting information based on international standards: Abstract of a dissertation for the degree of Doctor of Philosophy (PhD) in Economics. - T., 2019.

4. https://www.ifrs.org/issued-standards/listof-standards/ias-19-employee-benefits/ IFRS 19 Employee Benefits.

5. Maslov B.G., Nikitenko B.N. Transformation of Russian reporting Compliance with IFRS // Management accounting. - 2016. - No. 1.
6. Resolution of the President of the Republic of Uzbekistan "On additional measures for the transition to international financial reporting standards" No. PP-4611 dated February 24, 2020. 